\title{
ゴムの老化防止剤について
}

\section{Antioxidants of Rubbers}

\section{久保田威 夫* 栗 林 愿* Takeo Kubota Sunao Kuribayashi}

\section{I. まえがき}

ゴム製品の耐用寿命を出来るだけ延長せしめることは 人類の生活にゴムが導入されて以来，ゴム技術者及び化 学者にとつて大きな課題であつた。ゴム製品の寿命の延 長という目的のためにとられる手段は，勿論ゴム技術全 般にわたる問題であるが, 特老化防止剤の使用研究に よる効果恃目覚ましいるのがある。即ちゴム製品の寿命 に対して支配的な要因となるゴムの老化について若干の 考察を行い，更にこの老化を防止する目的で吾々がゴム 製品に実用している老化防止郕 (Antioxydant, Ageresister, Protective Agent, Anti-deteriorant) 决き 記述を試みた。

\section{II. ゴムの老化よ老化防止機構}

ゴムは未加琉又は加硫の状態の何れを問わず必然的に 老化なる現象を伴う。老化によつて生ずるゴムの状態の 変化は,ゴムの種類及び老化条件によって色々，と異り， 同一ゴムでもその未加硫か加硫ゴムであるかによつて， 観察される結果は違つたものとなつて来る。しかし何れ にしてる時日の経過沉よつて鲌裂を生じたり軟化又は硬 化したりして性能の溥化するのを避けることは出来な い。この老化を起す原因としては，熱，機珹的疲労，光， オゾン及び特殊金属（銅，マンガン）等とされるのであ るがこれら注何れも現象的分類した原因であり，本質 的注すべて酸化汇基づくものとされている。

（1）コムの酸化 ゴムはその不飽和性の故に空気 中の酸素によつて犯され，不飽和度の高い物質と違つて 極めて僅かの酸化によつてもその特性が著しく損ぜら れ，乙かもその酸化機構たるや極めて複雑なるのでその 解明は多くの人によつて試みられ幾多の学説がたてられ てきた。

Blake と Bruce ${ }^{1)}$ は生ゴムを空気又は酸素の存在の 下で光に曝し吸収された $\mathrm{O}_{2}$ の量を測定することにより 生ゴムの酸化はその厚さの函数となることを研究した。 そして，多くの老化防止削は生ゴムに於ける酸化汶対し

\footnotetext{
$*$ 横浜護謨製造株式会社（平塚市新宿 150）
}

ては防止効果よりむしろ促進効果を有することを認めて いる。勿論生ゴム飞於ける酸化は, ゴムの可塑化とい5 加工技術上の重要な根拠となつていることは言をまたな い。

加疏ゴムそ於汁る酸化は，未加䟽ゴム以上加疏ゴム の老化が激しいという理由汇らり, 重要であり, 従つて 老化防止㨈は大部分加琉ゴムの酸化を防止する目的で使 用されるものである。

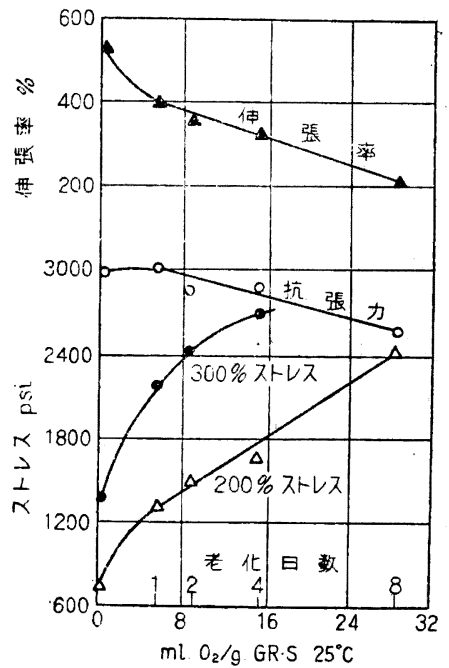

第1図 加硫ゴムの物理 性能に対する酸菜吸着の影響 $\left(100^{\circ} \mathrm{C}, 760 \mathrm{~mm}\right)$

ゴムの酸化現象の研究の一手段として, 酸素吸着速度 の測定がある。Shelton は第 1 図の如く酸素吸着量とゴ 么の物理牲能との関連性について研究し ${ }^{21}$ 更に温度と共 亿酸素の吸着量も增すととを，第 2 図の如く示した ${ }^{3 / 4) 。 ~}$ Tobolsky 等 ${ }^{5)}$ ほ然ゴムに吸着される酸素量に対する 光, 温度等の影響について検討し,何れる或一定の光度, 温度では，最大吸着速度を示すことを，吴験的及び理論 的険じた。

ゴムの炭化水素の酸化に於ける化学反応機構を解明す るためには, 炭化水素の自㗢酸化理論の導入が極めて有 矨であつた。炭化水素の自働酸化機構については古くょ 


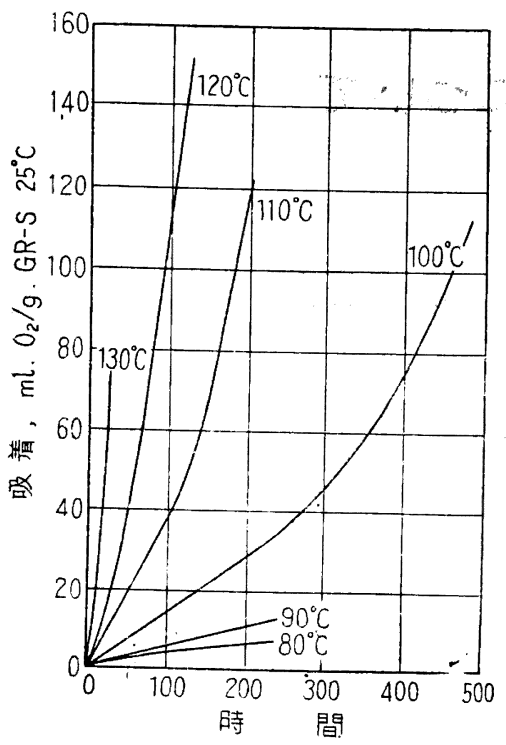

第2図酸素吸着に於ける温度の影響 $\left(760^{\circ} \mathrm{C}\right)$ り多くの人が研究して居り, それらは次の如く炭化水素 に対する酸素の攻撃によるフリーラジカル連銷反応式に よつて説明される(6)7。

(A) 反応の生起

$\mathrm{R} \cdot \mathrm{H} \stackrel{\text { 活性化 }}{\longrightarrow} \mathrm{R} \cdot+\mathrm{H}$

(B) 連鎖の伝播

$\mathrm{R} \cdot+\mathrm{O}_{2} \rightarrow \mathrm{RO}_{2} \cdot$

$\mathrm{RO}_{2} \bullet+\mathrm{RH} \rightarrow \mathrm{ROOH}+\mathrm{R} \cdot$

$\mathrm{ROOH} \stackrel{\text { 活性化 }}{\longrightarrow} \mathrm{R} \cdot, \mathrm{RO}:$ 等

(C) 連鎖の終結

$$
\begin{aligned}
& \mathrm{R} \cdot+\mathrm{R} \cdot \rightarrow \mathrm{RH}+\mathrm{R}(-\mathrm{H}) \\
& \mathrm{RO}_{2} \cdot+\cdot \mathrm{OH} \rightarrow \mathrm{ROH}+\mathrm{O}_{2} \\
& \mathrm{R} \cdot+\mathrm{R} \cdot \rightarrow \mathrm{R}-\mathrm{R}
\end{aligned}
$$

そしてこの反応の活性化は, 光, 熱, 機械的疲労, 銅 マンガン等による。 Hock ${ }^{8)}$ はシクロヘキセンについて，

•Robertson と Waters' ${ }^{9}$ はテトラリンについて, Bateman と Morris ${ }^{10)}$ はオレフィンの自甥酸化について, 夫々上記の如き考察を行つた。双 Bolland と $\mathrm{Gee}^{11)}$ の リノール酸エチルの酸化速度に関する実験より出発し て, Tobolsky ${ }^{5}$ 等は, ゴム炭化水素の自働酸化に於ける 最大速度の現象を認め, 鎖の切断反応の最大速度と連結 して論じた。

最近赤外線吸収スペクトルを用いて複雑な有機物質の 構造を知ることが可能となり，これをゴムの老化及び老 化防止剤の機構の探求沁用した例子多くなつて来た。

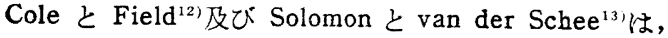
未加硫の天然及び合成ゴムの赤外線吸収スペクトルは，
熱老化又は光化学的老化汇よつて次の如き変化をするこ とを示した。即ち酸化の結果, $-\mathrm{OH}, \mathrm{C}=\mathrm{O}$ 基の存在を 示す新吸収带を認め, 二重結合を示す吸收帯の減少する ことにより, 酸化の結果, 二重結合は徐々に飽和され, 又 $\mathrm{CO}$ 基の生成することを認めた。

（2）酸化防止刘の機構 か」るゴム炭化水素の自 㗢酸化に対して酸化防止郕が如何なる機構の下にその効 果を挙げているのであらうか。ゴム中には必ず少量の不 純物質が存在する。この不純物の或物は酸化防止効果を 有するのであるが，未加硫ゴムが老化し難いのは，この 天然の酸化防止剤任負う処が大きいといわれる。この天 然の酸化防止剤の作用は, 共鳴安定化ラジカルを形成す ることにより，反応連鎖を絶ち切るのであつて, Waters ${ }^{6)}$ はこの酸化防止剤の作用機構について, これはパーオ キシド $\mathrm{RO}_{2}$ ・ラジカルを破壊するるのとみ市すべきであ つて，ハイドロパーオキシド分子 $\mathrm{ROOH}$ を破壊するの では亦いとした。

加硫ゴムの酸化及び酸化防止剤の作用機構 汇関し, Sbelton 及び $\operatorname{Cox}^{14)}$ はアミン型とフェノール型酸化防 止抄数種を選び，その効果を酸素吸収曲線などより比輐 検討し, Tobolsky 等 ${ }^{5)}$ の最大速度現象を認め, 且酸化 防止郕の作用機構を次の如く,フリーラジカル連鎖反応 方程式によつて説明した。

(A) 生 起

$$
x \cdot \mathrm{ROOH} \rightarrow n \mathrm{R} \cdot\left(\mathrm{RO} \cdot, \mathrm{RO}_{2} \cdot\right)
$$

$\mathrm{RH}+\mathrm{O}_{2} \rightarrow \mathrm{R} \cdot$

$\mathrm{AH}+\mathrm{O}_{2} \rightarrow \mathrm{A}$.

(B) 伝 播

$\mathrm{R} \cdot+\mathrm{O}_{2} \rightarrow \mathrm{RO}_{2} \cdot$

$\mathrm{RO}_{2} \cdot+\mathrm{RH} \rightarrow \mathrm{ROOH}+\mathrm{R}^{\cdot}$

(C) 連镍の交換

$\mathrm{RO}_{2} \cdot+\mathrm{AH} \rightarrow \mathrm{ROOH}+\mathrm{A} \cdot$

$A^{\cdot}+\mathrm{RH} \rightarrow \mathrm{AH}+\mathrm{R}$.

(D) 終 結

$2 \mathrm{RO}_{2} \cdot \rightarrow$ 安定物兵

$2 \mathrm{~A} \cdot$

$\mathrm{A}^{\cdot}+\mathrm{RO}_{2} \cdot \rightarrow \quad "$

(E) パーオキシドの崩犊

$x \cdot \mathrm{ROOH} \stackrel{\mathrm{AH}}{\longrightarrow}$ 安定物質

こ」に R・H はゴム炭化水素, $\mathrm{AH}$ は酸化防止郕とす る。即ち (A) 酸化防止剤浮対する直接酸素の攻慗によ る酸化連鎖の開始，(C) 酸化防止剤を含む連鎖の交換， (D) 酸化防止剤ラジカルが他のラジカンと反応して安定 物質を作り，酸化連鎖を停止する終結，(E) パーオキシ ドが分解して更に酸化を開始する如きフリーラジルを 
作るよりす安定物貿となつて終る。以上の如き段階炕よ つて酸化防止剤の作用機構を説明している。

Cole と Field ${ }^{12)}$ は GR-S 等の酸化を赤外線吸収スペ クトルKよつて研究し，次の如き結果を得た。酸化防止 用として PBNA (Phenyl- $\beta$-naphthylamine) を加えた GR-S $105^{\circ} \mathrm{C}$ にて 20 時間老化せる際の赤外線吸収 スペクトルの変化は, 酸化防止绪を加えないときに比し

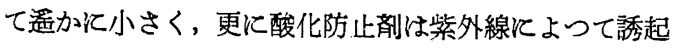
された酸化と対してより，熱酸化に対してより効果的で あることを認めた。又この際アセトン抽出等沉より， GR-S 中の PBNA が如何化変化したかを研究した処, PBNA ほゴムの酸化と共消費されることが判つた。 しかしながら PBNA は単独存在せる場合, 又はトル エン溶液として存在せるときは, $100^{\circ} \mathrm{C}$ 亿於て空気中の 酸素によつて何らの変化を受けないのであるから，この 第二級アミンの分解現象は, 酸化連鎖反応の終結の結果 として起つたのであると思われる。即ち次の如きフリー ラジカル反応によつて酸化連鎖を終結せしめる。

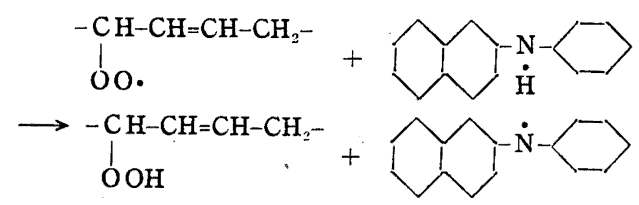

(A)

(A) の如きジアリルアミノラジカルは酸素と反応しな い。即ち共鳴に上る安定化のために,か」るラジカルは, ゴム炭化水素から $\mathrm{H}$ 原子をとつて, 新しい酸化連鎖を起 す程活性が大きくないるのと思われる。

油脂及び石油, ひいてはゴム等の炭化水素の酸化防止 䇌として用いられるフェノール采酸化防止剤の作用機構

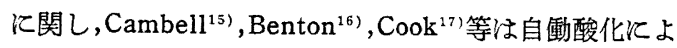
るフリーラジカル論的解䣋を行つた。即ち Benton ${ }^{16}$ はシ 第三ブチルーpークレゾールについて次の如く説明した。

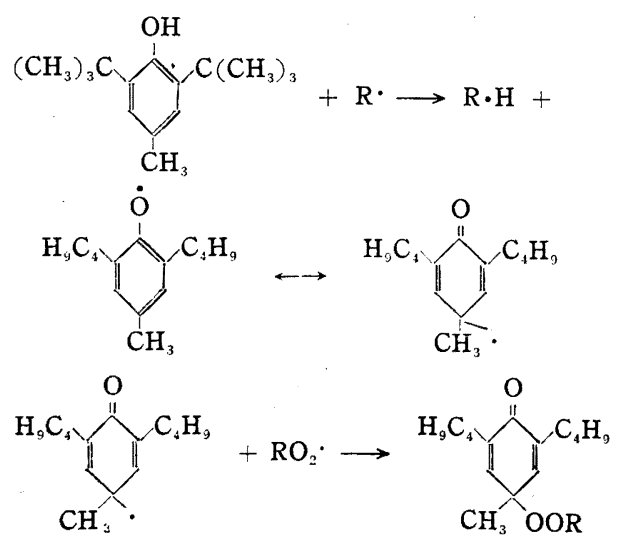

又 $\mathrm{Cook}^{17)}$ は次の如く考党た。

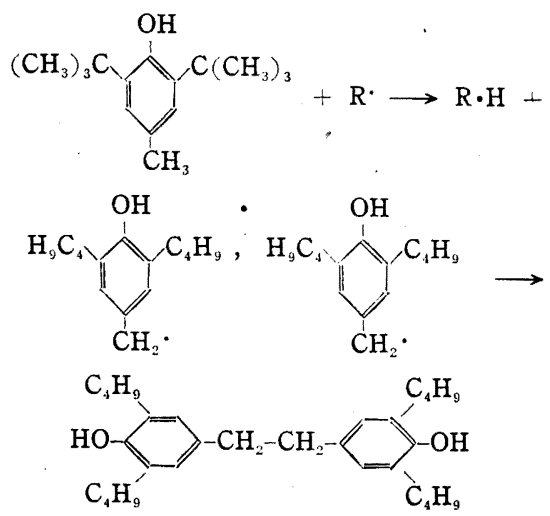

(B)

(B) は更に酸化防止的慟く。かくの如くゴム炭化水素 の酸化反応は連鎖機構によつて起りそれれによつて由来 する物理的変化は同時起るいくつかの型の反忘の集計 である。即ち架橋，環化及び連続重合で，これとよつて ゴム硬化し, 又これと反対汇鎖の切断反応があり，と れによつてゴムは粘着性を生じ, 抗張力を失うに至る。 従つてゴムの老化及び老化防止剤の作用機構を化学的手 法により直接解明することと平行して，いわば間接的 な物理的手法を用いて，架橋及び切断反応の相関的な速 度を分離測定することが，近来多くの人によつて研究さ れ，老化及び酸化防止剤の作用機構解明の有力な手段之 なつてきた。この物理的手段としてね，Viscosity 法， Sol-gel 関係, Stress-relaxation 及び Creep, 又は Permanent-Set 法等が用いられる ${ }^{18)}$ 。

\section{III. ゴムの老化防止剂}

ゴムの老化を防止する為にゴム混合する有機楽品を 老化防止郕という。吾々が現在実用している老化防止郩 の中, 主要なるのを次に分類した。

\section{(1) 第一級アミン類}

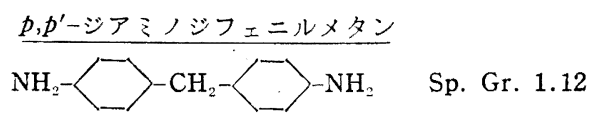

商品名例 Tonox。老防効果中位。フレックス, フロ スチング防止用。

(2) アルデヒド・アミン類

アルドールーム-ナフチルアミン

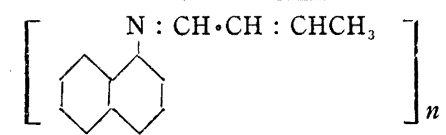

融点汇 $80 \sim 100^{\circ} \mathrm{C}$ 及び $140^{\circ} \mathrm{C}$ の二種あり, 前者を $\mathrm{A}$, 後者を $\mathrm{C}$ と呼ぶが, 両者共耐熱性は極めて大きく, 配合 
量を多くしてもブルーミングの危険はないが, 表面惺裂 に対しては弱い。

(3) 第二級アミン類

フェニルー $\alpha$-ナフチルアミン

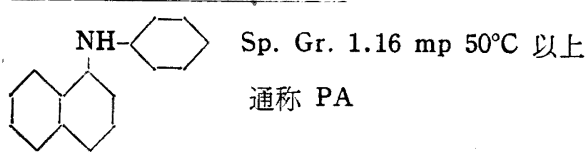

酸化, 屈撓軍裂汶対する抵抗泩が大きい。

フェニルー $\beta$-ナフチルアミン<smiles>C1CCC(NC2CCC3CCCCC3C2)CC1</smiles>
Sp. Gr. 1.18, mp 102 $108^{\mathrm{c}} \mathrm{C}$ 通称 $\mathrm{D}$

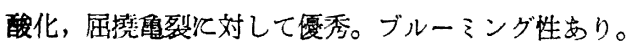
モノ及びジーヘプチルジフェニルアミンの混合物<smiles>[Mg]C=Cc1ccc(Nc2ccccc2)cc1</smiles><smiles>CCCCCCCC1CCCC(NC2CCCCC2)CC1</smiles>

Sp. Gr. 0.97. 商品名 Agerite Stalite。阿熱, 耐酸 化耐フレックス性大。アミン系中では非污染性である。

$\underline{N, N^{\prime}-シ シ フ ェ ニ ル ー p-フ ェ ニ レ ン ア ミ ン ~}$ $>\mathrm{NH}-\longrightarrow \mathrm{NH}-\longrightarrow \mathrm{mp} 145^{\circ} \mathrm{C}$ 通称 $\mathrm{H}$

屈撓象裂防止郕として特効的に使用される。ブルーミ ング性大なる為, 配合量は 0.5 以下が普通である。

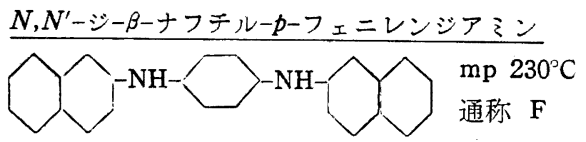

Agerite White とも呼以゙机，アミン采中で污染性が 少く，又銅毒防止郕として卓効がある。

（4）アセトン・アミン縮合重合生成物 アセトンとアニリンの反灾生成物

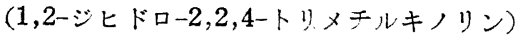<smiles>CC(C)NC1CCCCC1C</smiles>

mp $75^{\circ} \mathrm{C}$ のものを Agerite Resin $\mathrm{D}, \mathrm{mp} 120^{\circ} \mathrm{C} の$ すのを Flectol $\mathrm{H}$ という名で夫々市販されているが, 何れも耐熱性汇優り，フロスチングを防止するが表面重 裂飞は弱い。アルドールーム-ナフチルアミンの近代化し た熱老化防止剈として重要なものである。

\section{アセトンと $p-$ フニネテジンの反応生成物}

(6-エトキシ-1,2-ジヒドロ-2,2,4-トリメチルキ， リン)<smiles>CCOC1CCC2NC(C)(C)CC2C1C</smiles>

黒褐色の粘琱油で Santoflex AW と呼汇れ，熱及び 屈撓に強い。

\section{アセトンと $p$-アそノジフェニルの反応生成物}

(6-フェニル-1,2-ジヒドロ-2,2,4-トリメチルキ， リン)

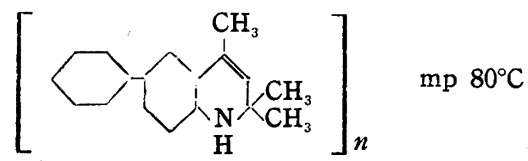

商品名 Santoflex B といい, 酸化及屈撓晴裂強い。 アセトンとジフェニルアミンの高温反応生成物

黒褐色粘稠油で $B-L-E 25$ 等の名で市販され，すべ ての老化江平均した効果を有する。

\section{(5) 混合アミン類}

後述する如く，吾々が老化防止剤を実用するときは， 多くの場合数種のものを組合わせて配合するが, 市販の 老化防止剤中には既飞数種のすのを湿合したものが少く ない。そしてそれらの多くのものは，次の例の如く，酸 化防止剤と屈撓重裂防止剤を組合わしたものである。

老防 HP

組成：フェニルー $\beta$-ナフチルアミン $66.69 \%$

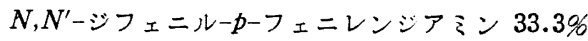

Santoflex BX

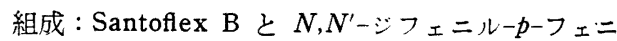
レンージアミン

Perflectol

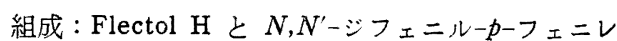
ンジアミン

(6) アルキルフェノール類

2,6-ジ第三ブチルーpークレゾール

$\mathrm{OH}$

$\left(\mathrm{CH}_{3}\right)_{3} \mathrm{C} \underbrace{}_{\mathrm{CH}_{3}} \mathrm{C}\left(\mathrm{CH}_{3}\right)_{3} \begin{array}{ll}\mathrm{mp} 70^{\circ} \mathrm{C} \\ \text { 商品名 Ionol DBPC } \\ \text { 等。 }\end{array}$

代表的な油脂の酸化防止剂で,ゴムに応用して低温酸 化防止剤となる。

2,5-シ第三ブチルーハイドロキノン

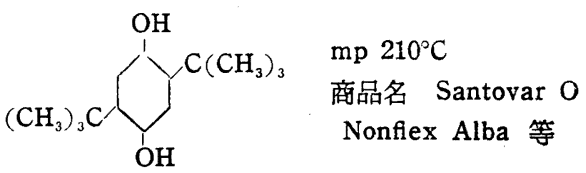


ハイドロキノンーモノペンジルエーテル

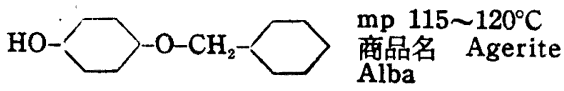

4,4'-ジヒドロキシーシフェニルシクロヘキサノン<smiles>CCCCCC(C)(C1CCCCC1)C1CCC(O)CC1</smiles>

(7) イミダソ゚ール類

2-メルカプトベンツイミダゾール

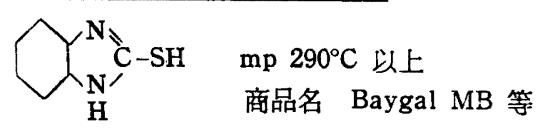

(8) ワックス類

Paraffine Wax, Micro-crystalline Wax, Heliozone Sunproof 等は表面重裂防止効果が大きい。

\section{IV. 老化防止㶡の特性}

ゴムの老化は酸化によると考劣れば，この酸化反応の 速度を抑党る作用をする老化防止剂はすべて広義の酸化 防止郕といえよう。しかし便宜上，ゴムの老化の直接原 因となる, 静的酸化, 熱老化, 機械的疲労, 光及びオゾ ンによる老化, 及び銅, マンガンによる老化等にゴムの 老化の型を分類し，夫々の老化防止郕が有している老防 特性はどの型と入るがより,てれを狭義の酸化防止㓮， 熱老化防止郕, 屈撓重裂防止剤, 表面電裂防止剤及び銅 毒防止剤等に分類するのであるが，その区別の判然とし ないものが多い。

次江吾々が老化防止刘を実用するに当つて，充分理解 しておかれね゙ならない項目について説明しょう。

（1）老化防止特性による老化防止剂の分類

（a）酸化防止剂（Anti-Oxidant）上述の如くゴム の老化防止剤恓すべて酸化防止剤であるが，こ」でいう のは狭義のそれで, 静的酸化, 即ち常温時学どの平常状 態於ける酸化に対して特低抗性をもつるのをいい, すべてのアミン系老化防止刘, フェノール系老化防止郕 を包含するが，特に酸化防止効果の大きいものは，第二 級アミン類，及びフェノール類で，充填郕の少い純ゴム 配合に於てはフェノール系が, 又カーボンブラックを多 く配合したゴムにはアミン系が夫々効果が大きいとされ $3^{14)}$ 。

（b）熱老化防止剂 (Anti-heat-deteriorant) ゴム 炭化水素の酸素吸着量と, その物理性能の低下とは明ら かに相関々係があり，又第 2 図の如く酸素吸着量は温度 と共僧加する。しかもゴム加硫物は，ごく僅かの酸素
の結合によつて，その物理的性質を大きく変化せしめら れるのである。この酸化反応を, 一般の化学反応と考元 て物理化学の常法を用いるととにより, Kemp ${ }^{19)}$ 等はゴ 么の酸化注対する温度恒数は, $10^{\circ} \mathrm{C}$ の変化に対して 2.0 〜2.5であるとした。しかしながら，この值は 80 100 以上飞なると次第に減少し，乙か同量の抗張力の低下 をるたらすと要する酸素の量は, 温度の上搨と共に著し く減少するという事実から，酸化によるゴムの老化は， 簡単な有機物質の酸化ではないということが推定され る。即ち高温沉於けるゴムの酸化は，常温時のそれとは や小趣を異にするであるらし，従つてこれに対応すべき

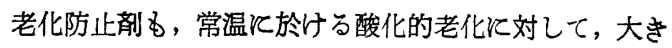
な抵抗性を有しているからといつて，必ずしも高温於 ける老化に対する防止生が優秀であるとはいえない。

例えば，フェノール系酸化防止刘柱，低温江於ける酸 化対しては，かなりの効果を有しているのであるが， 高温に於ける所謂熱老化に対しては殆んど効果がない。 か子る点から, 酸化防止郕の中, 特江耐熱老化防止滆と いう区分が行われるのである。

アミン系老化防止郕はすべて耐熱性を有してはいるの であるが, 特にアルヒイド・アミン類, 及びケトン・ア ミン縮合物の如く，一定の構造式を持たない，重合又は 縮合生成物性耐熱効果が大である。

(c) 屈撓重烈防止剂（機械的疲労防止剂）(Anti-fle ring Agent) 屆撓などの機械的疲労による龟裂発生 も一種の酸化炕よる現象である。即ち Neal と North$\mathrm{am}^{20)}$ は屈撓による老化について, その要因を研究し,

静的及び動的老化に於ける

老化防止剂の效果の比較

\begin{tabular}{|c|c|c|}
\hline \multirow{2}{*}{ 老 化防 止 剂 } & \multicolumn{2}{|c|}{$\begin{array}{c}\text { 老化防止剂の効果 } \\
\text { (相対値) }\end{array}$} \\
\hline & $\begin{array}{l}\text { ボムべに } \\
\text { よる老化 }\end{array}$ & $\begin{array}{l}\text { 屈撓によ } \\
\text { る老化 }\end{array}$ \\
\hline 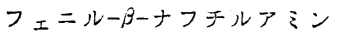 & 100 & 100 \\
\hline ジフェニルアミン. & 30 & 90 \\
\hline 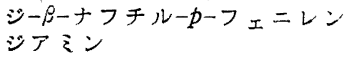 & 120 & 30 \\
\hline
\end{tabular}

この疲労現象は酸化の一つの型であると結論した。しか しこ〉飞観察される酸化現象は静的交条件下に於けるむ゙ のとは全く異つており,この疲労による老化は, 或種の 老化防止绪偟よつて遅らせることは可能であるが，上表 の如く, この老化防止戍が通常の酸化に於いて示すのと 全く違つた結果を示す場合が多い。

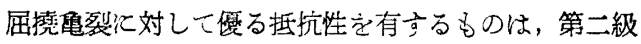
アミン類中, フェニレンジアミン類, ナフチルアミン類

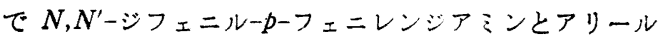
アミンの湿台物は, 屈撓重裂及び酸化現象に対して, 併 
用効果を示すといわれる。

（d）表面龟裂防止剂 (Anti-checking agent) 光 及びオゾンのゴムに対する作用は現象的にるよく似て居 り, 又化学的見地より, その作用機構任相点が多いた めに，同一の分類に入れて考えられることが多い。

光及びオゾンのゴムに対する作用は, 結果は酸化反応 に帰着するのであり, 光はこの反応を促進し，オゾンは 光又は放電現象によつて生成した活性化酸素として,ゴ ム飞作用するものと考它られる。

通常の酸化又は熱老化, 屈撓重裂等が, ゴム内面とか 表面とかを問わず, 全体に於て発生し, 外観上の変化は たいしてなく, 結合酸素量は極めて小さいのにもか」 わらず, 物理性能の低下が著しいのに対して, 光及びオ ゾンによる酸化反応は, ゴム表面に於てのみ行われ，外 観上, 大きな変化をきたし，化学的にもかなり変質する が, 加硫ゴムそのものの物理性能の低下はさほど大きく ないといつた特徴を有する。このように, 光及びオゾン の活性は非常に大きなものであるにもか〉わらず，光は ゴム内部に到達する程の透過力をもたず，オゾンはその 活性が過大なために，ゴム内部に㴓透する前に，ゴム表 面で分解し消費されてしまい，上記の如き特色ある老化 現象となつてあらわれるのである。

この光及びオゾンによる表面龟裂の防止剤として要求 される性質は, ゴムに対する親和性の小さく, 加硫後, ゴム面にブルームして，5すい膜面を形成し，しか子， この膜面が柔軟性に富み, ゴム面が外気に直接曝露され ることを防ぐことにより，表面重裂を防止するという点 であるが，このためには，古くよりパラフィン蠟が賞用 されてきた。最近このパラフィン蠟化代るべきるのとし て，マイクロクリスタリンワックスや，ヘリオン゙ーン， サンプルーフ等の特殊ワックス類が市販されるに至り, 更にとの効果を上げている。

（e）銅毒防止剂 (Copper-inhibitor) ゴムの老化 に対する銅及びマンガンの作用は，これら金属イオンの 酸化反応江対する触媒作用であるといわれ，これらの毒 性は合成ゴムより，天然ゴムの場合に，より大きなるの となる。

銅毒防止成として一般に用いられるものは， $N, N^{\prime}$-シ ー $\beta$-ナチルー $p$ ーフェレンジアミンでむる。

（2）老化防止剤の配合特性老化防止剈はその老 化防止特性の他に, ゴムに配合した際, そのゴム製品の 物理性に及ぼす影響について検討してみなければならな い。次にその項目について簡単に触れる。

(a) 加硫性能に及ぼす影些 多くのものは加硫性能に は大きな影響を与えないが，生バッチの可塑度，加硫速
度，加硫ゴムのストレスーストレイン性能などへの影響 を一応検討してみる必要がある。

(b) 污染性, 変色性 老化防止剂使用に当つて, 特次 白色乃至鮮明色ゴムに於て最も注意すべき性質の一つに 老化防止剤の污染性, 又は変色性がある。老化防止剤の 中で主要な地位を占めるアミン系物質は, その程度の大 小はあれ, 污染性又は光による変色性を避けることは殆 んど不可能である。污染性, 変色性のない老化防止剤の 要求は必然的に高まり, 最初油脂, 石油の分野の酸化防 止剤として用いられていたアルキルフェノール系物質が ゴムに応用されるに至り，この要求も一部充たすことが 出来た。即ちアミン系物質の中でる， $N, N^{\prime}$-ジ- $\beta$-ナフ チルーpーフェニレンジアミン等の如く, 比較的污染性の 小さいるのるあるのではあるが, 一般に非污染性, 非変 色性老化防止威はすべてフェノール系物質である。

（c）ブルーミング性 ゴムに配合された配合鼡のある ものは, 時日の経過と共に, 再び外部へ析出する所謂ブ ルーミング (Blooming) 現象を起すが, 老化防止剤のブ ルーミング性す実用上注意すべき問題である。老化防止 剤のブルーミング性は，そのゴムに対する溶解度の中位 のもの, 又は融点の中等度のもの, 或は絬晶能力の大な るものほど大きいといわれる。総体的に構造式の簡単 な, 明白なもので, ゴムの加硫温度で熔融し, ゴムに対 する溶解度が温度によつて大きく変るような物質はブル 一ミング性大きく，これに反して，ゴムに対する溶解度 が極めて大きいか, 極めて小さいるの, 及び, 縮合重合 生成物の如く非晶質の物質のブルーミング性は殆んぞ考 虑するに及ばない。

ブルーミング性の大きい老化防止㶡は, フェノール采 物質, 及びジフェニルーpーフェニレンジアミン等である。

（3）老化防止剤の使用老化防止肪をゴム製品に 奏用するに当つては，以上述べた如き特性をよく理解し た上で，適正な配合を行わなければならない。しかる吾 々が遭遇するゴム製品の老化は，決して単純なるのでは なく，数種の老化現象を併発することが多く，この為に 対応する老化の型の異つた数種の老化防止肪を組合わぬ た混合老化防止凨が多く市販されているのである。

又，より大きな老化防止効果を期待して，その配合量 を増すことは，必ずしすすべての場合に妥当であるとは いえず，老化防止猎怡は各々最適配合量とも考えられる ものがあり，それ以上配合量を増しても，むはや或一定 限度以上の効果が得られず，むしろ逆の効果を招来する 場合が多い。この最適量は，又ブルーミング限界量と関 連せしめることる出来, ブルーミング性の著しいるのは 多量配合しても直接老化防止機構に関与する有効部分は 
当然限定されて来るであろう。

\section{V.むすび}

以上, ゴムの老化及び老化防止理論の現況沉られ, 吾 イがゴム工業に於て実用している老化防止猎化ついて述 べたのであるが，これらの老化防止猎の中で，既に国産 化されて市販されているるのは次の如きすのである。

アルドールームーナフチルアミン, 老防 $\mathrm{A}$ 又はC

フェニルーム-ナフチルアミン。老防 PA

フェニルー $\beta$-ナフチルアミン。老防 $\mathrm{D}$

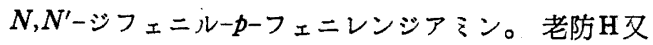
はP

$N, N^{\prime}$-ジー $\beta$-ナフチルーp-フェニレンジアミン, 老防 F 老防 $\mathrm{D}$ と老防 $\mathrm{H}$ の混合老防。老防 $\mathrm{HP}$

2,6-シ第三ブチル-p-クレゾール。Nocrac 100

2,5-ジ第三ブチルーハイドロキノン。 Nonflex Alba

4,4'-ジヒドロキシージフェニルシクロへキサノン。

Antigene W

2-メ゙ルカプトベンツイミダゾール。Antigen MB

以上の如く国産化された老化防止剮の品種は, 未だに 極めて少く, ゴム工業の要求に全面的に沿うことが出来 ず, 輸入品の使用を余儀なくされる不便が多かつたので ↔るが，これらゴム工業に於て要求される老化防止㧩の 国産化の問題决，ゴム技術者と合成化学技術者の
密接な連慗の下に, 強力に推し進める必要を痛感する次 第である。

\section{文献}

1) Blake, Bruce : R.C.T. 12, 181 (1939)

2) Shelton, Winn : Ind. Eng. Chem. 38, 72. (1946)

3) Shelton, Winn : Ind. Eng. Chem. 38, 71 (1946)

4) Shelton : Ind. Eng. Chem. 45, 2080 (1953)

5) Tobolsky : J. Am. Chem. Soc. 72, 1942 (1950)

6) Waters: Ann. Repts. on Progress Chem. 42, 130 (1945)

7) Frank: Chem. Rev. 46, 155 (1950)

8) Hock : Ber. 71, 1430 (1938)

9) Robertson: J. Chem. Soc. 1948 1574, 1578, 1585

10) Bateman : Trans. Faraday Soc. 48, 1149 (1952)

11) Bolland: Trans. Faraday Soc. 42, 236 (1946)

12) Cole : Ind. Eng. Chem. 39, 174 (1947)

13) Solomon: J. Polymer Sci. 14, 181 (1954)

14) Shelton: Ind. Eng. Chem. 46, 816 (1954)

15) Cambell : J. Am. Chem. Soc. 74, 1469 (1952)

16) Benton: Nature 171, 269 (1953)

17) Cook: J. Org. Chem. 18, 261 (1953)

18）例光ば Throdahl : Symp. on Aging of Rubbers (1949) 35 47

19) Kemp: Ind. Eng. Chem. 30, 1168 (1938); 31, 1472 (1939)

20) Neal: Ind. Eng. Chem. 23, 1449 (1931)
(46 頁より続く)

実験値 $2.98 \%$ 計算值 $2.96 \%\left(\mathrm{C}_{21} \mathrm{H}_{14} \mathrm{O}_{5} \mathrm{NSBr}\right)$

(15）1-アミノ-2-オキシ-3-ブロムアントラキノン (XX)の合成 XIX (mp 202 4 $\left.4^{\circ} \mathrm{C}\right) 0.5 \mathrm{~g}$ 濃硫酸 $\left(d_{4}^{15}=1.840\right.$ 約 $\left.95.5 \%\right) 5.0 \mathrm{cc}$ 飞とかし, 水水中に注 ぎ,こしわけた。赤褐色粉末 $\left[\mathrm{mp} 225 \sim 6^{\circ} \mathrm{C}\right.$ (分解) $]$ と してXX $0.3 \mathrm{~g}$ を得た。対理論収率約 $88 \%$ 。 $50 \%$ 眽酸か ら再結晶して褐色がかつた橙赤色釬状結晶 $\left[\mathrm{mp} 232^{\circ} \mathrm{C}\right.$ (分解)]を得た。窒素分析の結果はつぎのと颃りである。 試料 $7.520 \mathrm{mg} \quad \mathrm{N}_{2} 0.295 \mathrm{cc}\left(763 \mathrm{~mm}, 21^{\circ} \mathrm{C}\right)$

\section{実験值 $4.57 \%$ 計算值 $4.40 \%\left[\mathrm{C}_{14} \mathrm{H}_{8} \mathrm{O}_{3} \mathrm{NBr}\right]$}

エタノール溶液の吸収スペクトルを測定した結果は $\lambda_{\max }=524 \mathrm{~m} \mu, 554 \mathrm{~m} \mu$ であつた。

本研究飞際し御指導を賜つた東京工業大学鹤岡信三助 教授ならびそ協力して下さつた白岩正豊氏に感謝いたし ます。尚本研究の一部は文部省科学研究助成金飞よつた すのである。[有機合成化学協会研究発表会 (昭 29) 講 演発表]

(昭和 30 年 8 月 12 日受理)

$$
\text { 文献 }
$$

1) 内木: 有合化, 13, 126-132 (1955)

2) F. Ullmann: Ger. 282,493 (1914)
3) F. Ullmann, A. Conzetti : Ber. 53, 826 837 (1920)

4）青山外：昭和 26 年度文部省試験研究費による研 究報告集録 p. 116

5) H. Waldmann :J. pr. Chem. [2]. 130, 92 102 (1931)

6) L. Fieser : Textbook of Organic Chemistry 504 (1952)

7) G. Heller, K. Schülke : Ber., 41, 3627 (1908)

8) P.H. Groggins, H.A. Newton: Ind. Eng. Chem., 21, 369 (1929)

9) V.R. Kokatnur : J. Am. Chem. Soc. 41, 2098 (1919)

10) 内木: 有合化, 12,364 367 (1954)

11) Bayer \& Co. : Ger. 229,316 (1911)

12) Bayer \& Co.: Ger, 235,312 (1911)

13) Imperial Chemical Industries, Ltd. ; Brit. 489,172 (1938)

14) Fries, Schürmann : Ber. 52, 2182 2195(1919)

15) 内木: 有合化, 13, 72 78 (1955)

16) L. Fieser: Experiments in Organic Chemistry p. 366 (1941)

17) R.W. Hardacre, A.G. Rerkin : J. Chem. Soc. 1929, $180 \sim 193$ 